\title{
The analysis of the existing terminology related to a post-mining land use: a proposal for new classification
}

\author{
Urszula Kaźmierczak $^{1} \cdot$ Marek W. Lorenc $^{2} \cdot$ Paweł Strzałkowski $^{1}$
}

Received: 11 July 2016/ Accepted: 26 September 2017/Published online: 14 October 2017

(C) The Author(s) 2017. This article is an open access publication

\begin{abstract}
The article attempts to classify and standardize the terminology used in the literature related to a postmining land use. The following terms were discussed: restoration, reclamation, rehabilitation, land development and revitalization as well as their explicitness enabling one to understand the essence of a certain process properly. On the basis of the existing methods of post-mining areas development found in the literature on the subject, certain inaccuracies related to the terminology of ways of reclamation and methods of development were shown. This situation enables one to offer a new, developed and flexible classification of ways of reclamation including all the possible forms of post-mining land use. This classification considers methods of reclamation and restoration of utility value to post-mining areas on the basis of 6 general (ngen) and 23 specific ways (nspec), which terminology is unambiguous and leaves no space for doubts as to the interpretation. The essence of the offered classification is a possibility of joining general and specific ways into semantic combinations excluding possible inaccuracies in understanding. A possible form of notation of general and specific ways is as follows: $<$ general.specific $>$, $<$ general.specific,specific $>$ and, possibly, $<$ general + general. specific + specific $>$. This kind of approach enables one to consider each place individually, step out of the box and increase a number of semantic combinations from number $n_{\text {gen }}$ to number $n_{\text {gen }} * n_{\text {spec }}$. The offered classification may
\end{abstract}

Urszula Kaźmierczak

urszula.kazmierczak@pwr.edu.pl

1 Wrocław University of Science and Technology, ul. Wybrzeże Wyspiańskiego 27, 50-370 Wrocław, Poland

2 Wrocław University of Environmental and Life Sciences, ul. Grunwaldzka 55, 50-357 Wrocław, Poland also be successfully used in determining ways of rehabilitation, revitalization or land development.

Keywords Restoration - Rehabilitation - Reclamation . Land development · Post-mining areas · Rock mining

\section{Introduction}

After mining activities cease, the areas are considerably altered in comparison with their original state which, in many cases, is considered degradation or at least deformation of the environment. However, a newly created form may constitute a landscape diversion with a positive, intriguing or even inspiring impact on our senses (Baczyńska et al. 2017). In this case, the above-mentioned negative associations cannot be applied. It can also be noted that in some cases there is a natural self-dealing effect with the resulting anthropogenic form, giving very good and satisfactory result. In other cases, human interference seems to be helpful or simply necessary; still, this activity should be applied in accordance with the previously accepted principles. It seems that these principles should take three basic aspects into consideration. One of those are the existing natural conditions or terrain configuration, state of vegetation, presence of water bodies or watercourses and, in this context, the form and shape of the existing anthropogenic land transformation (e.g. excavation). The second aspect should be related to the existing objective conditions of the area, influencing the choice and application of the appropriate way of its development in the future. The third aspect means expectations and possible suggestions of local authorities and population who have their own adequately justified preferences and priorities concerning the future of this place. 
Ways and forms of post-mining areas development determine appropriate recommendations which are founded on the proper, specialist terminology. However, there are numerous inaccuracies and ambiguities of some terms and incomparability of classifications offered by different authors in the literature on the subject. What is more, the fact is that many of those offers force one to use a solution which is not fully optimal, satisfactory to neither local authorities nor residents. Moreover, the existing classifications of the post-mining land reclamation are difficult to correlate with one another. The use of one of them does not always correspond to the other. In addition, within the existing general reclamation directions, the possibility of allocating the relevant function to the designated area and indicating the specific ways of its use is also limited. It is feared that sites with similar natural conditions, using different classifications, will be differently reclaimed and redeveloped. For instance, determining a way of reclamation as, e.g. industrial one does not provide complete information on the functions, the particular area will have after mining ceases. One does not know whether this will be a public utility structure, industrial plant or service or sports facility. Similarly, determining a way of reclamation as agricultural one can be perceived as broadly taken crop cultivation or animal breeding. A lack of precise determination of these functions causes problems related to reclamation task planning and cost estimation of such an undertaking. Further according to Lima et al. (2016) for any given surface mining, the decisions should, in principle, be translated into site specific objectives. An example here can be "Wilcza Góra" basalt mine located in Poland. This mine has very general ways of reclamation determined, and these are aquatic and forest. Objectives formulated in that way are unclear since these only mean that the excavation pit will be filled with water and there will be a forest area formed around. One does not know detailed functions, thus it is unable to plan reclamation works or even its costs. Knowing the detailed functions proposed by the mining entrepreneur, namely natural, recreational and educational ones under the name of "Geodiversity Park," one is able to evaluate the range of reclamation tasks and their costs.

The article aims at recognizing and organizing the existing reality in this scope versus administrative and economic practices, opinions found in the literature on this subject and author's own research. The review of the current methods of the discussed areas' development, their appropriate compilation and in-depth analysis are offered, and consequently, these enable one to present a new, relatively developed and, simultaneously, possibly optimal and flexible offer of the classification.

\section{The analysis of the terms/terminology of returning the utility or natural functions to post-mining areas}

The analysis of the literature connected to the issues of returning the utility and natural functions to the areas after mining ceases shows application of many terms which may be used differently and often even improperly. The terms which occur the most often in the literature are as follows: restoration, reclamation and rehabilitation. Restoration means the process of the site condition replication after deposit exploitation. Restoration allows no land use flexibility and incurs the greatest cost (Sahu and Dash 2011; Dogan and Kahriman 2008; Bradshaw 1996; Sweigard 1992; Lima et al. 2016).

The term rehabilitation means the establishment of a stable and self-sustaining ecosystem, but not necessarily the one that existed before mining began (Dutta et al. 2005). Bradshaw (1996) uses that term as "the action of restoring a thing to a previous condition or status." This appears rather similar to restoration, but there is little or no implication of perfection. Indeed, in common usage, something that is rehabilitated is not expected to be in as original or healthy a state as if it had been restored. According to the USA National Academy of Sciences, it means that the land is returned to a form and productivity in conformity with a prior land use plan including a stable ecological state that does not contribute substantially to environmental deterioration and is consistent with surrounding aesthetic values. European Union law doesn't define the methods and directions of reclamation, as well as the principles of performing reclamation works. However, it defines the concept of rehabilitation as restore the land to a satisfactory state, with particular regard to soil quality, wild life, natural habitats, freshwater system, landscape and appropriate beneficial uses (Directives 2006/21/WE of the European Parliament and of the Council). Rehabilitation usually permits the greatest flexibility in future land use and incurs the least cost (Sahu and Dash 2011).

The term reclamation is mainly used in UK and in USA. In British terminology, reclamation is the process of gaining or recovering land, bringing it into a condition for cultivation or other use (Sweigard 1992). US National Academy of Sciences, however, treats this term as the site is hospitable to organisms that were originally present or others that approximate the original inhabitants. Reclamation infers that the pre- and post-disturbance land uses are nearly the same (Sahu and Dash 2011 after: Kuter 2013). However, this term may also be found in other publications discussing the issues of restoring the utility or natural values to post-mining areas (Dogan and Kahriman 2008; 
Cuff and Goudie 2009; Kaźmierczak et al. 2014; Sphiwe and Amponsah-Dacosta 2016; Lima et al. 2016).

All the aforementioned terms refer to the situation where returning natural or utility values to degraded areas takes place from the moment of cessation of a mining activity to the moment of possibility of using a fully equipped/developed area. However, in some countries, e.g. in Poland, there is a problem of terminology/definition of this phenomenon since legal regulations provide a clear division into two stages:

- (reclamation) the stage of restoring or giving the usable values to degraded or devastated lands by appropriate land relief shaping, water regulations, soil restoration, slopes reinforcement and road construction or reconstruction,

- (land development) the stage of agricultural, forestry or other use of reclaimed areas.

Here, it seems necessary to specify the terms concerning the restoring of altered post-mining areas' utility. Therefore, first of all, one should define more precisely the terms referring to the all-embracing solutions (without division into stages) which are eventually related to a possibility of full utilization of a post-mining area. The first term that should be used here would be restoration that should mean the return to the original state of the altered land, the state before degradation. The second one that should occur in this case is rehabilitation understood as the return to the utility/natural state according to the original land development plan. However, the return to the utility/natural state should be in accordance with the aesthetic qualities of the surrounding areas. One should bear in mind that this term should allow flexibility of choosing the method of development.

However, if there are stages in the restoring process of the usable or natural values, we propose to define them as follows:

- reclamation-understand as restoring or giving the usable values to degraded or devastated land by appropriate land modelling (ground works, slopes reinforcement), improvement of physical and chemical properties, water regulation, soils restoration and roads construction or reconstruction. This definition could also be used for preparing land for development.

- land development_-defined as target activities enabling one to use the reclaimed land, respectively, and in accordance with reclamation way and, consequently, land development method (e.g. utilities, buildings, appropriate infrastructure, e.g. sports and recreation).

However, one should notice that both these terms define the integrally and serially connected stages of land use since the method of future land development determines the way, scope and method of reclamation. Still, there is a freedom of attributing a function to the altered areas since it can be restoring functions land alteration or giving totally new ones. Therefore, there is a freedom of choice concerning the method of post-mining land development.

The literature also mentions the term revitalization. It is the term covering both stages: reclamation and land development, and it means the state restoration, giving the opportunity to perform the utility function of this area (Uberman and Ostręga 2003; Bielecka and Król-Korczak 2010; Juzyk et al. 2011; Pietrzyk-Sokólska 2012; Kuter 2013). The basic objective of revitalization is economic and social recovery (Kołodziej 2005), still an important aspect here is the fact that this process can take any form. (There is no obligation of restoring the altered land to its original functions.) What is more, revitalization should be all-embracing and involving a number of multi-connected, complementary and mutually reinforcing activities aiming at triggering a qualitative and positive change within a particular area.

\section{Literature research concerning the possibilities of using post-mining areas and the offer of classification of reclamation ways}

The most important aspect concerning restoring post-mining areas' utility values is determining functions they should have after the mining activity ceases. Currently, there is a very wide range of possibilities of post-mining areas use. One can, for instance, use an open cast for waste disposal, as a recreational area or to render different services. The natural values of post-mining excavations are noticed, allowing to reconstitute the environmental condition but different from the original one (Kaźmierczak et al. 2014; Jawecki 2012, Hao et al. 2010; Pavloudakis et al. 2009; McHaina 2001). The occurring different possibilities of post-mining areas use have resulted in many classifications of land development (and the resulting reclamation ways) or rehabilitation ways. The classification based on standards of the American Office of Surface Mining Reclamation and Enforcement (2000) is one of them, specifying the post-mining land uses (Table 1).

Other land uses are mentioned in the USA Code of Federal Regulations (2011) which defines ten methods of land use (Table 2).

An innovative classification of determining ways of reclamation was offered by Kaźmierczak and Malewski (2001) and Kaźmierczak (2002). A distinguishing feature of this classification was the division of ways into general and specific ones which are joined together in many semantic combinations. This approach was supposed to eliminate ambiguities and differences in the reclamation's 
Table 1 Methods of post-mining land uses according to the American Office of Surface Mining Reclamation and Enforcement (2000)

\begin{tabular}{ll}
\hline Post-mining land use & Description \\
\hline Forestry & Land used or managed for the long-term production of wood, wood fibre or wood-derived products \\
Agriculture & $\begin{array}{l}\text { Agricultural use including cropland, pastureland or land occasionally cut for hay, grazing land } \\
\text { Fish and wildlife habitat } \\
\text { Public facility use or } \\
\text { public use }\end{array}$ \\
$\begin{array}{c}\text { Protection of fish and wildlife habitat and related environmental values } \\
\text { recreational sites such as picnic areas, campgrounds, ball fields, tennis courts, fishing ponds, equestrian and off- } \\
\text { road vehicle trails, and amusement areas, together with any necessary supporting infrastructure such as parking } \\
\text { lots and rest facilities } \\
\text { Commercial operations would include retail or trade of goods or services, including hotels, motels, stores, } \\
\text { restaurants and other commercial establishments }\end{array}$ \\
$\begin{array}{c}\text { Industrial operations would include heavy and light manufacturing facilities, production of materials for fabrication } \\
\text { and storage of products }\end{array}$ \\
$\begin{array}{c}\text { Residential areas would include land used for single and multiple-family housing, mobile home parks or other } \\
\text { residential lodgings }\end{array}$ \\
Residential
\end{tabular}

Table 2 Methods of post-mining land use according to the USA Code of Federal Regulations (2011)

\begin{tabular}{|c|c|}
\hline Land use & Description \\
\hline Cropland & $\begin{array}{l}\text { Land used for the production of adapted crops for harvest, alone or in rotation with grasses and } \\
\text { legumes that include row crops, small grain crops, hay crops, nursery crops, orchard crops and other } \\
\text { similar crops }\end{array}$ \\
\hline $\begin{array}{l}\text { Pastureland or land occasionally cut for } \\
\text { hay }\end{array}$ & $\begin{array}{l}\text { Land used primarily for the long-term production of adapted, domesticated forage plants to be grazed } \\
\text { by livestock or occasionally cut and cured for livestock feed }\end{array}$ \\
\hline Grazing land & $\begin{array}{l}\text { Land used for grasslands and forest lands where the indigenous vegetation is actively managed for } \\
\text { grazing, browsing or occasional hay production }\end{array}$ \\
\hline Forestry & Land used or managed for the long-term production of wood, wood fibre or wood-derived products \\
\hline Residential & Land used for single and multiple-family housing, mobile home parks or other residential lodgings \\
\hline Industrial/commercial & $\begin{array}{l}\text { Land used for: } \\
\text { (1) Extraction or transformation of materials for fabrication of products, wholesaling of products or } \\
\text { long-term storage of products. This includes all heavy and light manufacturing facilities } \\
\text { (2) Retail or trade of goods or services, including hotels, motels, stores, restaurants and other } \\
\text { commercial establishments }\end{array}$ \\
\hline Recreation & $\begin{array}{l}\text { Land used for public or private leisure-time activities, including developed recreation facilities such } \\
\text { as parks, camps, and amusement areas, as well as areas for less intensive uses such as hiking, } \\
\text { canoeing and other undeveloped recreational uses }\end{array}$ \\
\hline Fish and wildlife habitat & $\begin{array}{l}\text { Land dedicated wholly or partially to the production, protection or management of species of fish or } \\
\text { wildlife }\end{array}$ \\
\hline Developed water resources & $\begin{array}{l}\text { Land used for storing water for beneficial uses, such as stock ponds, irrigation, fire protection, flood } \\
\text { control and water supply }\end{array}$ \\
\hline $\begin{array}{l}\text { Undeveloped land or no current use or } \\
\text { land management }\end{array}$ & $\begin{array}{l}\text { Land that is undeveloped or, if previously developed, land that has been allowed to return naturally to } \\
\text { an undeveloped state or has been allowed to return to forest through natural succession }\end{array}$ \\
\hline
\end{tabular}

terminology, e.g. sports and recreational is recreational and tourist way in other classification. The authors offered 5 general and 19 specific ways of reclamation (Table 3).

On the basis of the existing classifications and the implemented post-industrial land reclamation and development projects, Uberman and Ostręga (2003) made a list of reclamation ways (Table 4). The authors, while maintaining the division into general and specific ways of reclamation, additionally distinguished cultural and recreational ways in comparison with the classification offered by Kaźmierczak and Malewski (2001) and Kaźmierczak (2002).

German RAG Immobilien-MGG company supporting the regional restructuring programmes within the area of Ruhr Coalfield and Saar River, has worked out the classification of post-mining areas with regard to their future use (Ostrega 2004). This classification includes the following developments: 
Table 3 Classification of reclamation ways according to Kaźmierczak and Malewski (2001) and Kaźmierczak (2002)

\begin{tabular}{ll}
\hline $\begin{array}{l}\text { General way of } \\
\text { reclamation }\end{array}$ & Specific way of reclamation \\
\hline Agricultural & Cropping, breeding \\
Forest & Forestry, protection, recreation \\
Aquatic & Water management, recreation \\
Natural & $\begin{array}{c}\text { Nature reserve, landscape park, protected landscape area, species protection, nature monuments, inanimate nature } \\
\text { documentation site, ecological areas, landscape-nature protected complex, green areas }\end{array}$ \\
Economic & Housing, industry, services \\
\hline
\end{tabular}

Table 4 General and specific ways of reclamation and development according to Uberman and Ostręga (2003)

\begin{tabular}{|c|c|}
\hline $\begin{array}{l}\text { General } \\
\text { ways }\end{array}$ & Specific ways \\
\hline Cultural & Educational, contemplative, artistic \\
\hline Natural & Protection forms dependent on natural values, sodding, shrubs, greening \\
\hline Forest & Protection, forest cover, economic \\
\hline Aquatic & Recreation, economic \\
\hline Economic & Residential housing, campuses, tourist and hotel infrastructure, garages, industrial parks, service areas, landfill sites \\
\hline Recreational & $\begin{array}{l}\text { Sports facilities including winter sports facilities as, e.g. ski slopes, alpine slides, tourist routes, parks, pedestrian and cycle paths, } \\
\text { fitness trails, amusement parks, extreme sports centres, skate-parks }\end{array}$ \\
\hline Agricultural & Cropping, breeding \\
\hline
\end{tabular}

- agriculture,

- forest,

- housing,

- business,

- industry,

- recreation,

- mining usufruct,

- industrial wastelands,

- open space.

The year 2008 brought other classifications describing general and specific post-mining land uses (Dogan and Kahriman 2008; Soltanmohammadi et al. 2008; Narrei and Osanloo 2011; Bangian et al. 2012), while Dogan and Kahriman (2008) offered six general possibilities of using the lands with a specific description (Table 5), and Soltanmohammadi et al. (2008) as well as Narrei and Osanloo (2011) listed eight types of post-mining land use (Table 6). On the other hand, Bangian et al. (2012) showed alternative ways of using lands after mining distinguishing 5 general and 13 specific ways of their use.

In his publication, Kuter (2013) determined possible forms of general post-reclamation land uses without distinguishing specific post-mining land uses:

- The original land use,

- Afforestation, forestry,

- Agriculture,

- Nature conservation and wildlife,
- Hydrology,

- Recreation,

- Site improving,

- Special reserve,

- Settlement or industry,

- Solid waste or rubble storage area.

As the literature research on the classifications of ways of rehabilitation/reclamation/land development shows, post-mining areas may have different functions. However, these classifications are not always accurate and may cause certain inaccuracies as, for instance, in the classifications of Dogan and Kahriman (2008) and according to the USA Code of Federal Regulations (2011) which offer the same forms of land use twice (pastureland, agriculture) which leads to ambiguity if there is no specific description. On the other hand, in the classifications of Soltanmohammadi et al. (2008) and Narrei and Osanloo (2011) types of land use are overlapping, as in case of lakes and pools and intensive recreation. Both types are connected with water development of post-mining land. It should be pointed out that in some cases the classifications, only distinguishing general possibilities of post-mining land use, do not specify a precise function of the reclaimed area. For instance, when declaring a water way one does not know whether a particular area will function as a storage pond or as a swimming pool. Another example here can be the recreational way which in one case is relaxation in the greenery, in 
Table 5 Classification of general and specific land use according to Dogan and Kahriman (2008)

\begin{tabular}{ll}
\hline General land use & Specific land use \\
\hline Construction & Industry, housing, public buildings \\
Agriculture & Cultivation, productive grazing, marginal grazing, allotments \\
Forestry & Economic, marginal \\
Fishing & Economic, marginal \\
Recreation (intensive) & Sport, picnic sites, caravan and campsites, car parks, waters capes \\
Recreation (extensive) & Casual/public open space, country parks \\
Wildlife & Casual education, nature conservation/education \\
\hline
\end{tabular}

Table 6 Types of post-mining land use according to Soltanmohammadi et al. (2008) and Narrei and Osanloo (2011)

\begin{tabular}{ll}
\hline Land use types & Exercised post-mining land uses \\
\hline Agriculture & Arable farmland, garden, pasture or hayland, nursery \\
Forestry & Lumber production, woodland, shrubs and native forestation \\
Lake or pool & Aquaculture, sailing, swimming, etc., water supply \\
Intensive recreation & Sport field, sailing, swimming or fishing pond, etc., hunting \\
$\begin{array}{l}\text { Non-intensive } \\
\text { recreation }\end{array}$ & Park and open green space, museum or exhibition of mining innovations \\
Construction & Residential, commercial (shopping centre, etc.), industrial (factory, brick and block making, etc.), educational (university, \\
Conservation & Wildlife habitat, water supply (surface and groundwater) \\
Pit backfilling & Possibility of landfill (as a last resort) \\
\hline
\end{tabular}

other case, reposing near water tanks. What is more, the problem here is also the divergence in terminology of ways which define the same objectives as, for instance, economic in one classification, and as commercial in the other.

Given the described difficulties in the terminology, there was an attempt of creating a classification including all the possible methods of land use. On the basis of the previously offered classifications and the literature study, the possible ways of post-mining land reclamation are listed in Table 7. Obviously, this classification could also be successfully used with determining the ways of rehabilitation, revitalization or land development. The offered classification maintains the division into general and specific ways with regard to the general ways' insufficiency for a specific description of post-mining land's future functions. The so far scattered methods of land use are grouped by the assumed form, e.g. water-sports, breeding, flood control reservoir; forest-management, protection, recreation; etc. Therefore, 6 general and 23 specific ways are offered. The innovativeness and practicality of the offered classification consist in its considerable flexibility in use resulting from the possibility of joining and combining general and specific ways.

Agricultural reclamation aims at enabling one to carry out works related to agricultural production, agricultural and food processing, breeding or taking advantage of allotment gardens. On the other hand, the forest way's task is to increase forest resources and plantations and create places of rest for local communities (Fig. 1a). One of the specific functions is also developing protection forests.

The general water way of reclamation creates the following possibilities in post-mining excavations: water retention, water regulation, building bodies of water for recreational use or building potable water or flood control reservoirs. On the other hand, increasing, preserving or recreating natural resources or elements within a particular area is the objective of the natural way. This can be achieved by restoring of wildlife in the transformed site by industrial activity, preserving the interesting objects of in animated and animated nature as, such as anthropogenic rock exposure (Fig. 1b). What is more, this way also includes unconditioned vegetation encroachment through the so-called natural succession and land reclamation for green areas, the ones having aesthetical, recreational or health-promoting functions as: squares, parks, boulevards, promenades and even botanical gardens.

Building of residential, industrial, communal and service facilities as well as recreational and sports facilities is included in the economic way (Fig. 1c), and the reclamation objective in the cultural way is increasing aesthetical, artistic and scientific qualities (Fig. 1d). According to above, it is important to preserve and promote the artistic objects, related to the history of industry, in the developed area. 
Table 7 Offered classification of ways of reclamation

\begin{tabular}{|c|c|c|c|}
\hline $\begin{array}{l}\text { General way of } \\
\text { reclamation }\end{array}$ & $\begin{array}{l}\text { Functions of the general way } \\
\text { of reclamation }\end{array}$ & $\begin{array}{l}\text { Specific way of } \\
\text { reclamation }\end{array}$ & Description of the way of reclamation \\
\hline \multirow[t]{2}{*}{ Agricultural } & \multirow[t]{2}{*}{$\begin{array}{l}\text { Agricultural production and } \\
\text { agricultural and food processing }\end{array}$} & Cropping & $\begin{array}{l}\text { Arable land: orchards, meadows, permanent pastures, } \\
\text { workers' allotment gardens }\end{array}$ \\
\hline & & Breeding & Breeding: cattle, poultry, finishers, fish, etc. \\
\hline \multirow[t]{3}{*}{ Forest } & \multirow[t]{3}{*}{$\begin{array}{l}\text { Increasing forest resources and } \\
\text { plantations }\end{array}$} & Forestry & $\begin{array}{l}\text { At least } 0.10 \text { ha land covered with forest vegetation and } \\
\text { related to forest economy }\end{array}$ \\
\hline & & Protection & Forests recognized as specially protected \\
\hline & & Recreation & $\begin{array}{l}\text { Recreation: pedestrian and cycle paths, fitness trails, } \\
\text { playgrounds, promotional forest complexes }\end{array}$ \\
\hline \multirow[t]{2}{*}{ Aquatic } & \multirow[t]{2}{*}{$\begin{array}{l}\text { Increasing water areas, water } \\
\text { retention and regulation }\end{array}$} & $\begin{array}{l}\text { Water } \\
\text { management }\end{array}$ & Potable water, flood control, flow-through reservoirs, etc. \\
\hline & & Recreation & $\begin{array}{l}\text { Swimming areas, reposing near pools, water sports, } \\
\text { waterholes }\end{array}$ \\
\hline \multirow[t]{11}{*}{ Natural } & \multirow{11}{*}{$\begin{array}{l}\text { Preserving, proper use of and } \\
\text { recreating natural resources and } \\
\text { elements, especially wildlife } \\
\text { vegetation and animals as well as } \\
\text { natural complexes and } \\
\text { ecosystems }\end{array}$} & Nature reserve & $\begin{array}{l}\text { Preserving the natural state or slightly altered state of } \\
\text { ecosystems, specific animal and plant species, elements of } \\
\text { inanimate nature of considerable scientific, natural, } \\
\text { cultural or landscape significance }\end{array}$ \\
\hline & & Landscape park & $\begin{array}{l}\text { Area having natural, historical and cultural values, aiming at } \\
\text { preservation and promotion of these values in the } \\
\text { conditions of sustainable development }\end{array}$ \\
\hline & & $\begin{array}{l}\text { Protected } \\
\text { landscape area }\end{array}$ & $\begin{array}{l}\text { Area covering the areas standing out by their landscapes of } \\
\text { different types of ecosystems }\end{array}$ \\
\hline & & $\begin{array}{l}\text { Species } \\
\text { protection }\end{array}$ & $\begin{array}{l}\text { Protecting wildlife vegetation and animals and, especially, } \\
\text { rare and endangered species, as well as preserving species } \\
\text { and genetic diversity }\end{array}$ \\
\hline & & $\begin{array}{l}\text { Nature } \\
\text { monuments }\end{array}$ & $\begin{array}{l}\text { A single living or inanimate object or a group of such } \\
\text { objects, characterized by unique scientific, cultural, } \\
\text { historical memorial and landscape values and individual } \\
\text { features distinguishing them among other objects, } \\
\text { especially venerable and giant trees and shrubs of native } \\
\text { and foreign species, springs, waterfalls, rising spring, } \\
\text { rocks, ravines, glacial erratic, caves }\end{array}$ \\
\hline & & $\begin{array}{l}\text { Inanimate nature } \\
\text { documentation } \\
\text { site }\end{array}$ & $\begin{array}{l}\text { Documentation site is scientific and educationally } \\
\text { important, not emerging on the earth surface or visible on } \\
\text { the surface, places of occurrence of various geological } \\
\text { formations, fossils accumulations, mineral objects, } \\
\text { caverns, rock caves, exploited and discarded opencast and } \\
\text { underground workings }\end{array}$ \\
\hline & & Ecological areas & $\begin{array}{l}\text { Ecological areas are worth protecting fragments of } \\
\text { ecosystems of significant importance for biodiversity, } \\
\text { such as natural water reservoirs, field and forest ponds, } \\
\text { groups of trees and shrubs, swamps, peat bogs, dunes, old } \\
\text { river beds, rock outcrops, scarps, gravel banks, etc. }\end{array}$ \\
\hline & & $\begin{array}{l}\text { Landscape- } \\
\text { nature } \\
\text { protected } \\
\text { complex }\end{array}$ & $\begin{array}{l}\text { Protection of especially valuable parts of natural and } \\
\text { cultural landscape in order to preserve their aesthetical } \\
\text { values }\end{array}$ \\
\hline & & $\begin{array}{l}\text { Natura } 2000 \\
\text { areas }\end{array}$ & $\begin{array}{l}\text { The areas of specific types of natural habitats and animal } \\
\text { and plant species which are considered valuable } \\
\text { (significant to preserve the natural heritage of Europe) and } \\
\text { endangered within the whole Europe }\end{array}$ \\
\hline & & $\begin{array}{l}\text { Natural } \\
\text { succession }\end{array}$ & Vegetation encroachment through natural succession \\
\hline & & Green areas & $\begin{array}{l}\text { Areas covered with vegetation as: parks, squares, clearings, } \\
\text { boulevards, botanical gardens, promenades, etc. }\end{array}$ \\
\hline
\end{tabular}


Table 7 continued

\begin{tabular}{|c|c|c|c|}
\hline $\begin{array}{l}\text { General way of } \\
\text { reclamation }\end{array}$ & $\begin{array}{l}\text { Functions of the general way } \\
\text { of reclamation }\end{array}$ & $\begin{array}{l}\text { Specific way of } \\
\text { reclamation }\end{array}$ & Description of the way of reclamation \\
\hline \multirow[t]{3}{*}{ Economic } & \multirow{3}{*}{$\begin{array}{l}\text { Expanding industrial, communal } \\
\text { and service as well as } \\
\text { recreational and sports areas }\end{array}$} & Housing & Residential, summertime, hotel buildings, etc. \\
\hline & & Industry & $\begin{array}{l}\text { Industrial and communal buildings, industrial parks, } \\
\text { economic zones }\end{array}$ \\
\hline & & Services & $\begin{array}{l}\text { Service facilities (e.g. storehouses, parking lots, shops, } \\
\text { warehouses, etc.) and sports facilities (e.g. sports fields, } \\
\text { courts, swimming pools, motorsports, other sports } \\
\text { facilities including winter or aviation sports constructions, } \\
\text { etc.) }\end{array}$ \\
\hline \multirow[t]{2}{*}{ Cultural } & \multirow[t]{2}{*}{$\begin{array}{l}\text { Preserving and promoting artistic } \\
\text { objects and those connected with } \\
\text { the history of industry, memorial } \\
\text { sites }\end{array}$} & Scientific & $\begin{array}{l}\text { Forms of protection (historic monuments, culture parks), } \\
\text { theme paths, concert and conference halls, laboratories } \\
\text { e.g. natural ones, documentation archives related to the } \\
\text { history of industry, monuments and memorial sites, } \\
\text { museums (museums of industry: standard, heritage parks, } \\
\text { eco-museums) }\end{array}$ \\
\hline & & Artistic & $\begin{array}{l}\text { Exhibitions, exhibition and concert halls, galleries, theatres, } \\
\text { stages, cinema theatres, etc. }\end{array}$ \\
\hline
\end{tabular}

The essence of the offered classification is a possibility of joining the ways into semantic combinations in the following form: <general.specific $>$, <general.specific,specific $>$ and, possibly, $<$ general + general.specific + specific $>$. In this way, one obtains much more semantic combinations from number $n_{\text {gen }}$ to number $n_{\text {gen }}{ }^{*} n_{\text {spec }}$, and even $n_{\text {gen }} * n_{\text {spec }}+n_{\text {gen }} * n_{\text {spec }}$, simultaneously eliminating ambiguities of the previous classification resulting from equivocal character of a general way's name (e.g. water as a water sports area, rearing pond, flood control reservoir). The following examples are given:

- the post-mining area will be a rearing pond. The general way of reclamation will be agricultural and the specific one-breeding so it will be eventually described as: agricultural.breeding

- the post-mining area will be a single-family housing development together with service facilities (e.g. sports fields, playgrounds). In this case, the general way of reclamation would be economic, and the specific ones would be housing and services. This will be described as follows: economic.housing, services

- the post-mining excavation pit will be used as a swimming area, and there will be the adjacent developed green areas, natural succession areas and sports services facilities. The general ways will be: aquatic, natural and economic; and the specific ones will be: green areas, natural succession and services. This will be described as follows: aquatic.recreation, natural.green areas, natural succession, economic.services.

\section{Summary}

The proposals concerning methods and forms of land development after mining found in the literature on the subject are hardly applicable due to a lack of the unambiguous terminology of the issues of restoring this land's utility and natural values. Adopting an optimal way of post-mining land development by choosing from many, not entirely correspondent classifications, is all the more problematic if one considers the fact that there is no direct correlation of the basic terms which constitute the basis for the mentioned classifications. After the in-depth analysis and discussion on the following terms: revitalization, restoration, rehabilitation, reclamation and land development, there was an attempt to standardize the terminology and organize the state of facts. On the basis of the literature offers, a new compiled classification was created and presented in which the basic terminology is unambiguous and leaves no space for doubts as to the interpretation. The so far scattered methods of land use were grouped by the assumed form, e.g.: water-sports, breeding, flood control reservoir; forest-management, protection, recreation; etc. The new classification offers the methods of reclamation and restoration of post-mining areas' utility and natural values on the basis of 6 general and 23 specific ways taking into consideration all the possible ways of using these lands. The proposed classification, although having the form of a larger table, is a kind of compromise, formed on the basis of those existing in the literature. It contains many elements proposed previously, but it also allows greater flexibility of adaptation of the appropriate functions and the general and detailed directions of development. It was also presented a very convenient proposal including the 

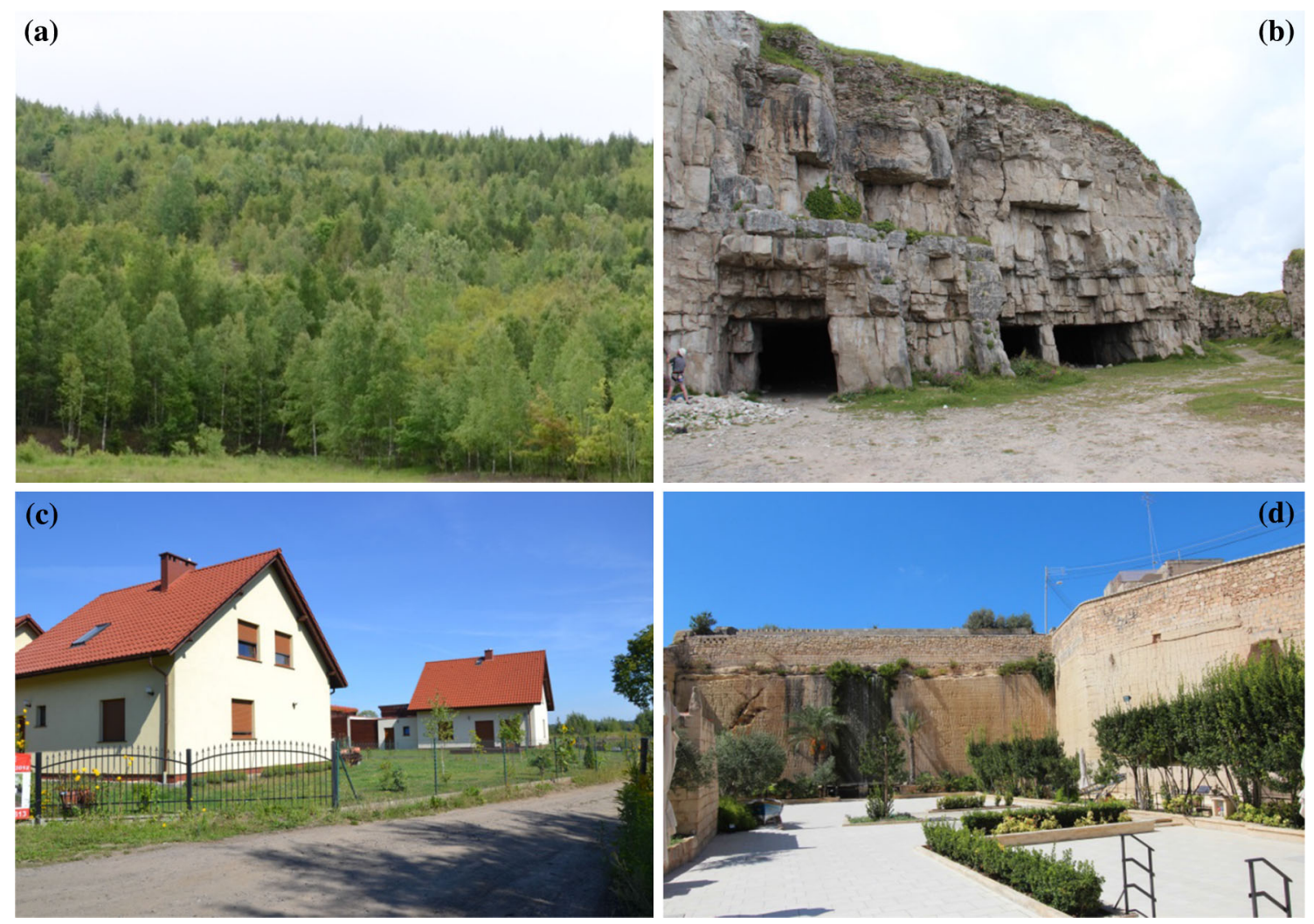

Fig. 1 Development of post-mining areas in the following ways a forest (external dumping ground of "Turów" Brown Coal Mine, Poland; b natural-anthropogenic rock exposures (Winspit, England);

c economic-housing development (Poland); d cultural-limestone pit developed for educational purposes, "Limestone Heritage Park and Gardens" (Malta)

connection the several models of land development. This will make possible to eliminate potential incompatibilities and the unjustified allocation of different functions to similar functions. This kind of approach will enable one to consider each place individually, avoiding stereotyped solutions which are often inapplicable to a specific site and unsatisfying in relation to social expectations. The proposed reclamation/rehabilitation plans systematics should be applied in the both general and detailed form. Only such precise clarification of the post-mining land function will allow the accurate estimation of the scope and cost of reclamation/rehabilitation.

Acknowledgements This scientific work was co-financed by Statute Research Studies (order S50099).

Open Access This article is distributed under the terms of the Creative Commons Attribution 4.0 International License (http://crea tivecommons.org/licenses/by/4.0/), which permits unrestricted use, distribution, and reproduction in any medium, provided you give appropriate credit to the original author(s) and the source, provide a link to the Creative Commons license, and indicate if changes were made.

\section{References}

American Office of Surface Mining Reclamation and Enforcement (2000) Postmining land use. http://www.osmre.gov/lrg/docs/ mtpmlureport.pdf. Accessed 24 May 2016

Baczyńska E, Lorenc MW, Kazmierczak U (2017), The landscape attractiveness of abandoned quarries. Geoheritage, 1-15. doi: 10 . 1007/s12371-01-0231-6

Bangian AH, Ataei M, Sayadi A, Gholinejad A (2012) Optimizing post-mining land use for pit area in open-pit mining using fuzzy decision making method. Int $J$ Environ Sci Technol 9(4):613-628. doi:10.1007/s13762-012-0047-5

Bielecka M, Król-Korczak J (2010) Hybrid expert system aiding design of post-mining regions restoration. Ecol Eng 36:1232-1241

Bradshaw DA (1996) Underlying principles of restoration. Can J Fish Aquat Sci 53:3-9

Code of Federal Regulations (2011) http://www.gpo.gov/fdsys/pkg/ CFR-2011-title30-vol3/xml/CFR-2011-title30-vol3-sec701-5. xml. Accessed 26 May 2016

Cuff DJ, Goudie AS (2009) Global change. Oxford University Press, Oxford

Directive 2006/21/EC of the European Parliament and of the Council of 15 March 2006 on the management of waste from extractive industries and amending Directive 2004/35/EC

Dogan T, Kahriman A (2008) Reclamation planning for coal mine in Istanbul, Agacli Region. Environ Geol 56:109-117. doi:10.1007/ s00254-007-1144-5 
Dutta S, Rajaram R, Robinson B (2005) Chapter 5: Mineland reclamation. In: Rajaram V, Dutta $S$ (eds) Sustainable mining practices-A global perspective. AA Balkema Publishers, London, UK, pp 179-191

Hao G, Yin Y, Xianke Y, Lichang Y, Di S, Liying M (2010) Study on ecological characteristic and reclamation in Xianshui coal mining area, Guizhou, China. Int J Min Reclam Environ $24: 18-33$

Jawecki B (2012) Minies in the landscape of Strzelin CountrySelected examples of land-use after mineral excavation areas. Architektura Krajobrazu Landsc Architect 37(4):24-34 (in Polish)

Juzyk A, Kudełko J, Szczerbiak A (2011) Investing in the pastMinig heritage-prospects of local development. 11 AltvergbauKolloquium VGE Verlag GmbH: 275-281

Kaźmierczak U (2002) Gospodarcze, przyrodnicze i przestrzenne funkcje górnictwa skalnego okolic Wrocławia. Dissertation, Wrocław University of Science and Technology, Wroclaw, pp $1-100$

Kaźmierczak U, Malewski J (2001) Koncepcja systematyki kierunków rekultywacji. Kopaliny Pospolite 7:9-10 (In Polish)

Kaźmierczak U, Strzałkowski P, Baszczyńska M (2014) Natural, geotouristic and recreation attractiveness on post-mining "Górażdże" areas. In: XXVII international mineral processing congress, IMPCmare 2014, Santiago, pp. 10-20

Kołodziej J (2005) Rewitalizacja dziedzictwa przemysłowego i jego rola w rozwój turystyki industrialnej. In: Burzyński T, Łabaj M (eds) Dziedzictwo przemysłowe jako atrakcyjny produkt dla turystyki i rekreacji. Doświadczenia krajowe i zagraniczne, GWSH, Katowice, pp 309-310 (in Polish)

Kuter N (2013) Reclamation of degraded landscapes due to opencast mining. Adv Landsc Architect, Chapter 33

Lima AT, Mitchell K, O'Connell DW, Verhoeven J, Cappellen P (2016) The legacy of surface mining: remediation, restoration, reclamation and rehabilitation. Environ Sci Policy 66:227-233

McHaina DM (2001) Environmental planning considerations for the decommissioning, closure and reclamation of a mine site. Int $\mathbf{J}$ Min Reclam Environ 15:163-176
Narrei S, Osanloo M (2011) Post-mining land-use methods optimum ranking, using multi attribute decision techniques with regard to sustainable resources management. Int J Sustain Dev 2:65-76

Ostręga A (2004) Sposoby zagospodarowania wyrobisk i terenów po eksploatacji złóż surowców węglanowych na przykładzie Krzemionek Podgórskich w Krakowie. Dissertation, AGH University of Science and Technology, Kraków, p 136 (in Polish)

Pavloudakis F, Galetakis M, Roumpos Ch (2009) A spatial decision support system for the optimal environmental reclamation of open-pit coal mines in Greece. Int $\mathrm{J}$ Min Reclam Environ 23:291-303

Pietrzyk-Sokólska E (2012) Geological environment as an important element of the reclamation and revitalization of the quarries. AGH J Min Geoengin 36:267-274

Sahu HB, Dash S (2011) Land degradation due to mining in India and its mitigation measures. In: Proceedings of the 2 nd international conference on environmental science and technology, IPCBEE vol 6. IACSIT Press, Singapore, pp 132-136

Soltanmohammadi H, Osanloo M, Razaei B, Aghajani Bazzazi A (2008) Achieving to some outranking relationships between post-mining land uses through mined land suitability analysis. Int J Environ Sci Technol 5:535-546

Sphiwe EM, Amponsah-Dacosta F (2016) A review of problems and solutions of abandoned mines in South Africa. Int J Min Reclam Environ 30:279-293. doi:10.1080/17480930.2015.1044046

Sweigard R (1992) Reclamation. In: Hartman HL (ed) SME mining engineering handbook, vol 1, 2nd edn. Society for Mining, Metallurgy and Exploration Inc, Littleton, p 1181

Uberman R, Ostręga A (2003) Metoda projektowania zagospodarowania dużych i zróżnicowanych kompleksów poeksploatacyjnych. In: Kształtowanie krajobrazu terenów poeksploatacyjnych w górnictwie, materials international scientific conference, Kraków, Poland (in Polish) 